\title{
NATIONALITY STATISTICS AND RUSSIAN POLITICS IN THE MID-NINETEENTH CENTURY
}

\author{
Darius Staliūnas
}

\begin{abstract}
In the first half of the nineteenth century the polyethnic nature of the Russian Empire was not a serious problem for its ruling elite. However, ongoing modernization processes and various nationality problems forced the government to pay attention to the ethnic variety of the state. Endeavours to rule the large empire more effectively and certain political reasons led to the taking of nationality censuses. The present paper deals with the causes of the censuses in the Northwest Province of the Russian Empire (in what is now Lithuania and Belarus) in the mid-nineteenth century, with the changes that the gathering of the material underwent and with the use of the collected data for political purposes.
\end{abstract}

Nationality statistics should not be seen merely as an ideological tool. The authorities were in need of nationality statistical data to ensure more effective administration and assessment of the results of their nationality policies. Nevertheless, nationality censuses served ideological aims, too. That was attested by the increasing mistrust of the authorities in statistical data, presented by 'the Poles' (mostly by the Catholic clergy). Although Russian ethnographers had placed emphasis on language as a criterion handy for the imperial government in the definition of the nationality of the common people, even in the mid-nineteenth century priority was often given to faith rather than language. That demonstrated how deep-rooted was the equation between faith and nationality in Russian public discourse at that time. Meanwhile as far as the social elite was concerned, national identity was specified by faith, culture, political aspirations and language, too. Although ideologically it was sometimes more convenient to emphasize the Russian or Lithuanian origin of the majority of the gentry, ethno-political reality prevented this from being done with any consistency.

Nationality statistics were used in order to 'prove' that the region was allegedly not Polish but Russian. Other arguments, largely historical, were used as well. 
In the early nineteenth century polyethnicity had not yet become a major political issue in the Russian Empire. ${ }^{1}$ In essence, no attempts were made to modify the domination of the ethnically non-Russian social and political elite on the fringes of the Empire, if it was loyal politically. Correspondingly, there were no accurate statistical data about the ethnic composition of the Empire and, in particular, its fringes.

This paper presents an analysis of the factors which encouraged nationality censuses in the former lands of the Grand Duchy of Lithuania (after the Uprising of 1863-64 known as the Northwest Province of the Russian Empire), and changes in the techniques of data gathering and the criteria of nationality. ${ }^{2}$ In the discussion of these issues one is immediately confronted with terminology. The point is that the censuses dealt both with ethnicity (plemennoi sostav) and with nationality (raspredelenie po narodnostiam). The use of different terms per se does not necessarily imply different notions. Therefore it is the task of the present author to establish to what extent the censuses dealt with inherited features distinguishing separate groups which could be defined objectively, and whether attention was paid to self-definition, political orientation and to faith.

Dealing with national censuses one cannot ignore ethnographic studies. And that is so not only due to the fact that the contemporary sciences had not yet been differentiated - say, an association, containing the word 'geography' in its name, could also engage in ethnographic, statistical and other kinds of research. Ethnography, conceived in Russia as Volkskunde (i.e. a branch of science concerned with one's 'own' people) rather than Völkerkunde (dealing with non-European nations), was very important for national statistics in the period when there were no modern national censuses, based on information obtained from surveys. Ethnography facilitated the localization of national groups and the establishment of nationality criteria.

1 For many valuable comments and suggestions, I wish to thank Zita Medišauskienè, Reda Griškaite and Vladas Sirutavičius.

${ }^{2}$ Concerning some of the censuses of the first half of the nineteenth century, see V. Sirutavičius, 'Tautiškumo kriterijai multietninių visuomeniu statistikoje. XIX a. vidurio Lietuvos pavyzdys’, Lietuvos istorijos metraštis, 1998 metai (Vilnius, 1999), pp. $74-85$. 
Recording Ethnic Variety Prior to 'the Great Reforms' The 1897 general census of the Russian Empire, has been dealt with quite extensively recently by historians, who have paid attention to the issue of nationality in their research. ${ }^{3}$ However, even earlier the officials of central institutions visiting the Northwest Province were concerned with 'the observation of the ethnic variety of the population' ${ }^{4}$ and the local authorities, in particular the governors, used to characterize the national variety of the region. ${ }^{5}$ It should be noted that in their yearly reports the governors were obliged to indicate the numbers of non-Orthodox believers (inovertsy) and aliens (inorodtsy) since the 1840s. Nevertheless, the latter information, supplied by the leaders of the gentry, local police officers, the Treasury Chamber and other institutions lacked accuracy. ${ }^{6}$ Besides, local officials interpreted the term inorodtsy in various ways. Since 1835 this category also comprised the Jews. ${ }^{7}$ In 25 reports writtten between 1857 and 1868 by 25 governors of Vilna (Vilnius), Kovno (Kaunas), Grodno, Minsk, Mogilev and Vitebsk, only the governor of Minsk attributed the Jews to the category of inorodtsy, while others assigned only the Tartars and Karaites to this group. ${ }^{8}$ Local officials themselves did not trust the statistical data that they supplied. ${ }^{9}$ Oddly enough, in the censuses the number of Jewish women always exceeded considerably the number of men - in this manner they evaded taxes. At the

${ }^{3}$ Die Nationalitäten des russischen Reiches in der Volkszählung von 1897, eds. H. Bauer, A. Kappeler, B. Roth (Stuttgart, 1991); D. W. Darrow, 'Census as a Technonlogy of Empire', Ab Imperio, no. 4, 2002, pp. 145-176.

${ }^{4}$ A copy of Konstantin Arsen'ev's report of 26 May 1845 to the Interior Minister, RGIA, f. 1290, op. 1, d. 149, fo. 1.

${ }^{5}$ Report of the Kovno governor (1843), RGIA, f. 1281, op. 4, d. 139 (1843), fo. 10; A copy of the report of the Kovno governor (undated, most probably of 1849), RGIA, f. 1281, op. 4, d. 3, (1849) fo. 22.

${ }^{6}$ V. M. Kabuzan, Narody Rossii v pervoi polovine XIX v. Chislennost' $i$ etnicheskii sostav (Moscow, 1992), pp. 8, 76, 77, 90, 91, 95.

7 J. D. Klier, 'The Concept of "Jewish Emancipation" in a Russian Context', Civil Rights in Imperial Russia, eds. O Crisp and L. Edmondson (Oxford, 1989), pp. 132-133; J. W. Slocum, 'Who, and When, Were the Inorodtsy? The Evolution of the Category of "Aliens" in Imperial Russia', The Russian Review, vol. 57, 27 April 1998, pp. 182-184.

${ }^{8}$ The reports of the Minsk governor for 1861, 1863, 1864 and 1866, LVIA, f. 378 , ap. 121 , b. 899 , fo. 5 ; b. 901 , fo. 10 ; b. 550 a, fo. 47 ; b. 913 , fo. 7.

9 The Mogilev governor's report for 1862, LVIA, f. 378, ap. 121, b. 1110 , ff. 34-35. 
same time, when faith was indicated, the rabbis showed more accurate numbers. The authorities, however, failed to disclose the falsifications. ${ }^{10}$

In addition to the official interest in the national composition of the Empire, there were some organizations which were also concerned with similar issues. In this respect the Russian Geographical Society should be mentioned in the first place. It was founded in 1845, and in 1849 it was given the epithet 'Imperial' (henceforth IRGS). The sphere of interest of the IRGS was much wider than its name would imply - it was also concerned with statistics and ethnography, attended to by separate divisions in its organizational structure. The Society should not be treated as a 'purely' scholarly institution, the tasks of which would be completely different from those of the authorities. As was shown by Nathaniel Knight, the 'scholarly' vision of the so-called 'German' faction of the IRGS was ousted by a pragmatic 'Russian' conception, oriented to the concrete needs of the state; it was represented by the so-called 'enlightened bureaucrats' (led by the Miliutin brothers). ${ }^{11}$

The unquestioned authority for contemporary Russian scholars and publicists was the Czech scientist Pavel Šafarik, whose works were translated into Russian. Šafarik maintained that nations should be categorized not only according to physical differences, but also drawing on the historical, and in particular linguistic, data. A perfect language, based on its original, pure and unique grammar, was the irrefutable evidence of an independent nation. ${ }^{12}$

One of the founders of the IRGS Academician Piotr Keppen, who maintained contacts with Safarik, worked also in the field of nationality statistics. In his research he used available sources, including the data from official inspections. The IRGS failed to persuade the authorities that during inspections data should be gathered on nationality statistics as well. Keppen was disappointed with the quality of the material collected, and he turned to the Orthodox Synod with the aim of receiving information from local

${ }^{10}$ Kabuzan, Narody Rossii, p. 83.

${ }^{11}$ N. Knight, 'Science, Empire, and Nationality. Ethnography in the Russian Geographical Society, 1845-1855', Imperial Russia: New Histories for the Empire, eds. J. Burbank and D. Ransel (Bloomington, Ind., 1998, pp. 108-141.

12 P. I. Šafarik, Slavianskiia drevnosti. Chast' istoricheskaia, 1, books 12 (Moscow, 1848). 
clergymen. The latter, however, also demonstrated a very low level of statistical competence, and the information they sent contained such phrases as 'the inhabitants of the Slavonic faith', 'the local people of the Muslim ethnic group', etc. In their attempts to display their learning, some priests mentioned even such historical tribes as could be found only in Povest 'vremennych let. ${ }^{13}$ Keppen did not manage to process these data. However, his works (The Ethnographic Map of European Russia, the article 'New Data about the Number and Locale of the Lithuanian Ethnic Group', etc.) witness his endeavour to collect the data of nationality statistics in a consistent manner.

In historical literature Keppen is presented as a most objective expert for having significantly contributed to the collection of relevant data. ${ }^{14}$ However, nationality statistics and discussions by statisticians at international congresses in the middle of the nineteenth century clearly show that the criteria adopted by the experts depended on a particular national paradigm prevalent in a particular country. The French maintained that in the census a question on nationality was senseless, because there was only one nation in France; Austrian ethnographers (Karl von Czoernig, among others) believed that individual answers to questionnaires were insufficient, and that they had to be complemented by scholarly ethnographic research; the Germans gave priority to language, albeit again the final decision had to be taken by the expert rather than by the individual whose nationality was being established. ${ }^{15}$ The differences between the French and German principles lay in the nationality conceptions dominant in those countries.

Keppen did not identify faith with nationality ${ }^{16}$ and, as can be judged from his article on the Lithuanians, he did not prioritize any single criterion, because in his opinion the Žemaitians differed from the Lithuanians 'in dialect, character, customs and beliefs' ${ }^{17}$; admittedly, in some cases language, or rather, the dialect of the people was

${ }^{13}$ Kabuzan, Narody Rossii, pp. 12-14.

${ }^{14}$ Ibid., pp. 7-14.

15 E. Brix, Die Umgangssprachen in Altösterreich zwischen Agitation und Assimilation. Die Sprachenstatistik in den Zisleithanischen Volkszählungen 18801910 (Vienna, 1980), pp. 23-24, 70, 78 ff.

${ }^{16}$ Keppen, Ob etnograficheskoi karte Evropeiskoi Rossii (St Petersburg, 1853), p. 17.

${ }^{17}$ Keppen, 'Novyia svedeniia o chislennosti i obitalishchakh litovskago plemeni', Zhurnal Ministerstva Vnutrennikh Del, part 34, 1851, p. 101. 
considered the main criterion. ${ }^{18}$ This principle enabled Keppen to deduce that over a hundred thousand Lithuanians in the Grodno Gubernia, mentioned in the official statistics, are actually Belorussians. ${ }^{19}$ In addition to these objective criteria, Keppen gave prominence to self-definition: 'Is it possible that a person could not be aware whether he was a Tartar, a Tunguz or a Russian?'. ${ }^{20}$ Nevertheless, this approach of Keppen's should not be overestimated. As already indicated, even Austrian and German experts trusted the identification of nationality actually to experts, because national self-consciousness was still too weak in many cases. It would be strange if Keppen could exaggerate the opinion of the individuals in Russia, where the processes of national consolidation lagged behind those in Western and Central Europe. It should also be taken into consideration that having expressed doubts about the official statistical data of the Grodno Gubernia, he indicated language as a reliable criterion.

Objective criteria were brought to the fore by the Lithuanian public figure Adam Kirkor. A member of the statistics committee of the gubernia turned editor of the official newspaper Vestnik vilenskii, he was no ordinary representative of official statistics. This essay is too limited in scope to discuss the metamorphoses of his ethnocultural and political orientations, ${ }^{21}$ therefore suffice it to observe that in his hierarchy of identities possibly the most significant factor was Lithuanianness, which in this case was perceived as regional identity. In other words, he identified himself with the historically

${ }^{18}$ It is possible that Pavel Kukolnik, a special official for history and statistics at the governor general of Vilna provided Keppen with necessary information. In 1849 Kukolnik circulated to the priests a questionnaire with the aim of receiving information on the language their parishioners used in their everyday communication and for prayer; see Sirutavičius, 'Tautiškumo kriterijai, p. 80.

${ }^{19}$ Kabuzan, Narody Rossii, p. 10.

${ }^{20}$ Ibid., p. 12.

21 On Kirkor, see M. Stolzman, Czasopisma Wileńskie Adama Honorego Kirkora (Cracow, 1973); idem, 'Wydawnictwo drukarni obywatelskiej w Wilnie (1859-1867)' Roczniki biblioteczne, z. 1-2, 1973, pp. 109-19; S. Kirkor, Przeszłość umiera dwa razy. Powieść prawdziwa, (Cracow, 1978); A. Kulakauskas, "'Šaka, atskilusi nuo tautos..." Lietuvos bajorijos ir LDK bajoriškosios kultūros vaidmuo lietuviu tautiniame atgimime', Sietynas, vol. III (Vilnius, 1998), pp. 75-98; Z. Medišauskienè, 'Adomas Honorijus Kirkoras: tarp Lietuvos, Lenkijos ir Baltarusijos', Lietuviu Atgimimo istorijos studijos, vol. 8 (Vilnius, 1996), pp. 168-193; D. Staliūnas, 'Lietuviškojo patriotizmo pèdsakai XIX a. viduryje', Lietuvos istorijos metraštis 2000 metai, 2001, pp. 310-325; idem, 'Bažnytinès unijos projektas (1865-1866)', Lietuviu kataliku mokslo akademijos metraštis, 20 (2002), pp. 127-140, ff. 
conditioned region - Lithuania, dominated by the high Polish-language culture. However, Kirkor valued the local people's (Lithuanian and Belorussian) cultures as well. It is noteworthy that he was an adherent of legalism, i.e. he was for the cooperation with the authorities for the sake of the country's well-being. Thus, according to official terminology, Kirkor was a 'Pole', however, in 1853, when he published an article on the statistics of the Vilna Gubernia, this aspect did not play any greater role in the assessment of the material he presented. 'Polish' science was not yet a priori considered biased. Besides, fixing a boundary between the Lithuanians and Slavs in the Vilna Gubernia, Kirkor was drawing on the Lithuanian historian Teodor Narbutt, who was also a 'Pole' in the eyes of the authorities.

According to Kirkor, the plemena (tribes, ethnic groups) are historical entities, defined by objective criteria. Therefore their boundaries can be fixed in two ways. First, it is possible to investigate their toponymy and relate it to their dialects. This technique has its drawbacks, since in the course of history the plemena mixed up and took over one another's customs, etc. The second way would be the analysis of the old folk legends and their comparison with the data of the chronicles and dialects as well. Thus, drawing on Narbutt, Kirkor maintained that the boundaries of the plemena could be determined on the basis of language and toponymy, on the customs, legends and chronicles. ${ }^{22}$ Ethnic delimitation was necessary for the establishment of the numbers of different plemena.

Thus, before the beginning of the 'Great Reforms', the determination of the ethnical variety was part of a scholarly rather than political or ideological issue.

\section{The Beginning of the Epoch of 'the Great Reforms' Moderni-} zation from above encouraged the authorities, in particular the 'enlightened bureaucrats' to pay attention to the ethnic variety of the Empire, since that, according to Dmitrii Miliutin, could be an obstacle to the reforms. The Ministry of War was also concerned with statistics, in particular thanks to Miliutin. It was the officers of the General Staff who gathered statistical information (including data on the national composition of the population) in the Northwest Province and in other areas of the Empire in the latter half of the 1850s. The impending abolition of serfdom in the greater part of the Empire

${ }^{22}$ Kirkor, Statisticheskii vzgliad na Vilenskuiu guberniiu, Istoricheskistatisticheskie ocherki Vilenskoi gubernii (Vilnius, 1853), p. 13. 
urged the political and intellectual elite to think about the future ethno-cultural orientation of the population, especially on the fringes of the Empire. Thus, for instance, the reform of primary education which started in the late $1850 \mathrm{~s}$, required information about the linguistic situation - in primary schools tuition could be conducted only in the language which pupils could understand. This problem was particularly urgent in the ethnically-mixed regions. Thus the implementation of these reforms alone required information about the national distribution of the population. On the other hand, the concern with nationality statistics witnessed the modernization of the Empire, giving prominence to the people and attaching importance to ethnicity and nationality as tools of political legitimization. Attaching significance to nationality statistics disrupted the hierarchical conception of estate society. In the middle of the 1850 s there appeared literary ethnography, the task of which was not only to gather information about the various ethnic groups on the fringes of the Empire, but also to integrate the people (narod) somehow with the Empire and its literate part of society. ${ }^{23}$ The IRGS also made its contribution by publishing fieldwork results; an article by M. Lebedkin contained information about the national composition of the Northwest Province. ${ }^{24}$

Both the officers of the General Staff and Lebedkin used nationality statistics collected by parish clergy on Keppen's initiative. Besides, the officers themselves applied to the local authorities and clergy requesting information according to specially prepared questionnaires. ${ }^{25}$ Information was supplied by local statistics committees, local police and individuals. Some officers made use of 'Polish' sources, too. ${ }^{26}$

${ }^{23}$ C. B. Clay, 'Russian Ethnographers in the Service of the Empire, 18561862', Slavic Review, vol. 54, no. 1, 1995, pp. 45-61.

${ }^{24} \mathrm{M}$. Lebedkin, 'O plemennom sostave narodonaseleniia Zapadnago kraia Rossiiskoi imperii', Zapiski Imperatorskago Russkago Geograficheskago obshchestva, book 3, (St Petersburg, 1861), pp. 131-160.

${ }^{25}$ Files 'Po tsirkuliarnomu predpisaniiu G. Ministra Vnutrennikh Del, o soobshchenii statisticheskikh svedenii ofitseram Generalnago shtaba pri sostavlenii imi opisanii gubernii', LVIA, f. 388, ap. 1, b. 248; ,Ob okazanii sodeistviia ofitseram Generalnago shtaba pri sostavlenii imi opisanii gubernii ${ }^{\circ}$, LVIA, f. 567, ap. 4, b. 684; 'O dostavlenii statisticheskikh vedomostei Grodnenskoi gubernii Kapitanu Buliavskomu', LVIA, f. 605, ap. 8, b. 249 and elsewhwere.

${ }^{26}$ Materialy dlia geografii $i$ statistiki Rossii, sobrannye ofitserami generalnago shtaba. Vilenskaia guberniia, sostavil generalnago shtaba kapitan A. Koreva (St Petersburg, 1861), pp. ii, iv-v, ff. 
Although the officers had enlisted the support of the local authorities, they often complained of the unwillingness of the local clergy to come to their aid, and the answers to the questionnaire seldom were satisfactory. Pavel Bobrovskii, who gathered information about the Grodno Gubernia, stated that the replies of the Catholic clergy about the diocese of Vilna contradicted even 'the physical laws of the existence of humankind'. ${ }^{27}$

Data were obtained not on the basis of interviews, but by 'experts' who decided what the results of nationality statistics should look like. Criteria for determining nationality seem not to have been uniform. The officers of the General Staff did not indicate in advance counting techniques, they simply asked for population numbers to be given according to their 'ethnic origin' (po plemenam); ${ }^{28}$ and only later, having received dusty answers, did they produce more detailed instructions on determining nationality.

In establishing the ethnic boundaries, the language or dialect were given the key role, and linguistic data was supplemented by historical reflections, differences in customs, toponymy (Narbutt's influence) and the observations of the authors themselves. ${ }^{29}$ The importance of the historical dimension was illustrated by the description of the Kovno Gubernia. D. Afanas'ev, drawing the line between the Žemaitians and Lithuanians, did not take into account linguistic criteria, he meant the territory of the former Duchy of Žemaitija, and the Nevėžis River formed the eastern boundary of Žemaitija. ${ }^{30}$ Some of the authors stressed the need not to mix faith and ethnicity:

The Slavs fall into two groupings: the Russians and the Poles. In the western gubernias all Catholics consider themselves Polish, applying the

${ }^{27}$ Bobrovskii to the Catholic Spiritual Consistory of Vilnius, letter of 19 Nov. 1859, LVIA, f. 604, ap. 4, b. 1649, fo. 22.

${ }^{28}$ Koreva to Vilnius governor general, report of 17 Aug. 1857, LVIA, f. 388, ap. 1, b. 248, ff. 3-4; Bobrovskii to the Lithuanian Orthodox Spiritual Consistory, letter of 9 July 1859 , LVIA, f. 608 , ap. 8, b. 249, ff. 21-22; Bobrovskii to the Catholic Spiritual Consistory of Vilnius, letter of 12 July 1859, LVIA, f. 604, ap. 4, b. 1618 , fo. 182 .

${ }^{29}$ Materialy ... Vilenska gubernia, p. v, 287; Materialy dlia geografii $i$ statistiki Rossii, sobrannye ofitserami generalnago shtaba, vol. 2: Grodnenskaia gubernia, sostavil chlen Imperatorskogo Russkago Geograficheskago obshchestva, generalnago shtaba podpolkovnik P. Bobrovskii (St Petersburg, 1863), pp. 619-620.

30 Materialy dlia geografii $i$ statistiki Rossii, sobrannye ofitserami generalnago shtaba, vol. 1: Kovenskaia gubernia, sostavil D. Afanas'ev (St. Petersburg, 1861), p. 311. 
term Russians to all Orthodox. However in regard to the origin of nationalities such a division is pointless. It is odd to mix faith with the origin of the nationalities, which appropriated a certain language and certain traits of the character. Here a Roman Catholic does not know and does not want to know that his forefathers could have been Orthodox. ${ }^{31}$

Thus ethnic origin is an attribute which the individual acquires through birth and which he should not disavow. Even the author of this quotation, Bobrovskii, was forced to acknowledge that the ethnic origin could not always determine nationality: 'A Catholic who is Russian by origin places himself in a different milieu - though he is a Slav, his heart does not belong to Russia any more'. ${ }^{32}$ The importance of faith was emphasized even more categorically by I. Zelenskii: 'Though, with very rare exceptions, both Catholics and Orthodox belong to the same plemia as the Belorussians, Black Russians and Polesians, the issue of their faith has become absolutely fundamental, since it has resolved another still more complex question of nationalities'. ${ }^{33}$ Meanwhile in the description of the Vilna Gubernia Koreva noted that the majority of 'the inhabitants of Slav origin', with the exception of 'the Poles' were Orthodox, and the Lithuanians were Catholics, though not as a rule, as there were Catholics among the Slavs as well. ${ }^{34}$

Although these descriptions of the Lithuanian and Belorussian gubernias were a constituent part of the collection and publication of the statistical data covering other parts of the Empire, they clearly reflected the political situation of this region. While still gathering the material, Bobrovskii wrote that the results of this work would have to renounce Polish fabrications. ${ }^{35}$ Some authors argued that that region was Russian rather than Polish. The arguments, however, varied: the faith of the population was considered essential in the case of the Minsk Gubernia, where the Orthodox predominated, ${ }^{36}$ while emphasis was laid on ethnic origin and language for the

31 Materialy ... Grodnenskaia gubernia, p. 614.

${ }^{32}$ Ibid.

${ }^{33}$ Materialy dlia geografii $i$ statistiki Rossii, sobrannye ofitserami generalnago shtaba, vol. 3: Minskaia gubernia, sostavil I. Zelenskii (St Petersburg, 1864), p. 418.

${ }^{34}$ Materialy ... Vilenska gubernia, pp. 288, 321.

${ }^{35}$ Bobrovskii to the dean of Vlodav, letter of 9 Dec. 1859, LVIA, f. 605, ap. 8 , b. 249 , fo. 63 .

${ }^{36}$ Materialy ... Minskaia gubernia, p. 418. 
Grodno Gubernia. ${ }^{37}$ The substantiation of the choice between faith and ethnicity in defining Russianness could doubtless be related to the concept of nationality advocated by the authors. In this connection one more aspect is worth noting. In different contemporary statistics from the Minsk Gubernia the ratio between the Orthodox and the Catholics (according to Zelenskii 698,134 Orthodox and 182,764 Catholics $^{38}$ ) and between the Russians (all Eastern Slavs were regarded as Russian) and the Poles differed insignificantly, though the predominance of the Russians would be more obvious if the count was conducted according to ethnic groups. Meanwhile the situation was quite different in the Grodno Gubernia. According to the data compiled by Bobrovskii, the Orthodox made up 54 per cent and the Catholics about 34 per cent; and the ethnic count showed 78 per cent were Russians and about 10 per cent were Poles. ${ }^{39}$ This time the linguistic criterion highlighted by the ethnographers and nationality statisticians suited the 'political request' very well. The deteriorating political situation on the western fringes of the Empire added greater urgency to the data of nationality statistics.

Facing 'the Polish Challenge' Religious and political manifestations, which started in the Polish Kingdom early in 1861, soon reached the Northwest Province, and the impending uprising added new exigencies to the data on the national composition of the fringes of the Empire. The Russian political elite increasingly perceived that 'concord' with 'the Poles' was impossible, and new strategies of nationality politics were necessary. One of the new tactics, discussed at the start of $1860 \mathrm{~s}$, was placing reliance on other ethnic groupings (Ukrainians, Belorussians as well as Lithuanians), which in essence meant setting off the peasantry against the Poles. There were proposals to back the ethno-cultural development of the Ukrainians and Belorussians (to set up schools with instruction in the national languages, to introduce these languages as academic subjects in schools of secondary and tertiary education, etc) ${ }^{40}$ Other officials emphasized the affinity of the Belorussians and Ukrainians to the tripartite Russian nation and suggested that the

${ }^{37}$ Materialy ... Grodnenskaia gubernia, pp. 619-620.

${ }^{39}$ Materialy ... Grodnenskaia gubernia, pp. 107, 615, 688.

${ }^{40}$ A secret unidentified letter of 25 Febr. 1862, forwarded by the tsar to the minister of internal affairs, Iz del Zapadnogo komiteta: Svod predlozhenii $i$ vyvodov, Russian National Library, St Petersburg, Russkii fond, 18.241.8/1-29 (unnumbered pages). 
Russianness of those ethnic groups should be seen as a counter to the Poles.

Thus, nationality statistics were necessary in the aftermath of the new political imperatives not only for ideological reasons but also for the implementation of the new national policy. First of all, 'evidentiary material' was necessary to show that the country was Russian, i.e. that Russians predominated in its population, that they were autochthonous, while the Poles were newcomers. Just at that time (about 1863) the phrase 'local origin' was replaced by 'Polish origin' in the definition of the Pole - 'a person of Catholic faith and local origin' became 'a person of Polish origin and Catholic faith'. The contents of the definition did not change (Polish origin typically indicated that a particular individual was born in the West Province), while autochthony, implied by the phrase 'local origin', could no longer be attributed to the Poles. The institutionalization of this conception had to be supported by nationality statistics, ethnographic and historical research.

Nationality statistics was also necessary taking into consideration political practice. Thus, in order to weaken Polish influence, the governor general of Vilnius Vladimir Nazimov suggested that the principle of proportional representation be adhered to in official institutions ${ }^{41}$ (although it sounds demagogic taking into account the situation at that time the ideas of this kind were expounded in confidential letters). Such data were necessary for redrawing administrative boundaries, too. ${ }^{42}$

Some departments, in particular those of the Ministry of Internal Affairs, possessed certain data related to nationality statistics, which had not been gathered systematically. Some officials even exaggerated the problem by stating that 'at the end of the 1850 s not a single national institution of the Empire possessed accurate data on statistics and ethnography of the western gubernias of Russia' ${ }^{43}$ Therefore, facing 'the Polish challenge' voices were increasingly heard about the necessity of collecting 'accurate', 'scientificallybased' data of the nationality statistics of the Western region. Russian ethnographic and historical 'scientific' research was to refute the

${ }^{41}$ Vilna governor general to minister of internal affairs, letter of 14 March 1863, RGIA, f. 1282 , op. 2, d. 339, fo. 40.

${ }^{42}$ Ibid., fo. 32.

43 P. N. Batiushkov, Belorussiia i Litva. Istoricheskiia sud'by SeveroZapadnogo kraiia (St Petersburg, 1890), p. xv. 
Polish and other foreign inventions about the history and ethnical composition of this region. ${ }^{44}$

In May 1862, i.e. at the time when the activity of the so-called 'Whites' increased (on 8-15 May their well attended congress took place, and the authorities knew about it) ${ }^{45}$ the governmental authorities tried secretly to gather data about the number of 'the landowners of non-Polish origin' in the Western provinces. ${ }^{46}$ Possibly in this way an attempt was made to ascertain on which section of the social elite the authorities could still rely. However, local officials had great difficulty in collecting such data. On the one hand, local governors complained that the indicated documents simply did not contain the data on the origin of the landowners. ${ }^{47}$ On the other hand, the interpretation of the term 'origin' varied. Thus, the governor of Kovno determined the origin according to the family names. The list of 'the landowners of non-Polish origin' of the Kovno Gubernia did not comprise a single person whose name had a Polish ending. ${ }^{48}$ In other cases faith was crucial: 'In the registers of the estates only the first names and surnames are indicated. That is not sufficient for the correct determination of the faith since due to different local conditions Russian or German families are Catholic and vice versa'. ${ }^{49}$ The Mogilev governor presented only a list of 'the landowners of nonCatholic faith' because he could not gather the information on the origin secretly as was requested by the central authorities. ${ }^{50}$

The need of nationality statistics led to the organization of an ethnographic statistical expedition to the Western province. The idea seems to have originated in the Department of Ethnography of the

${ }^{44}$ Batiushkov, a copy of the letter 'On the Polish element in our Western gubernias', presented to Tsarina Mariia Aleksandrovna on 25 Sept. 1862, Russian National Library, Manuscript Division, f. 52, d. 47, ff. 9-10.

${ }^{45}$ Vilnius governor general to the minister of internal affairs, a confidential letter of 16 May 1862, RGIA, f. 1282, op. 1, d. 31, fo. 31; S. A. Lazutka, Revoliutsionnaia situatsiia v Litve 1859-1862 gg. (Moscow, 1961), p. 205.

${ }^{46}$ Minister of internal affairs to the governors general of Vilna, Kovno and Grodno, a copy of a secret letter of 19 May 1862, LVIA, f. 378, 1862, ps, b. 37, fo. 2.

${ }^{47}$ Grodno governor to the minister of internal affairs, letter of 2 June 1862 , RGIA, f. 1282, op. 2, d. 365, fo. 60.

${ }^{48}$ Nominal list of the landowners of non-Polish origin of the Kovno Gubernia, ibid., ff. 101-103.

${ }^{49}$ Vitebsk governor to minister of internal affairs, letter of 25 May 1862, ibid., fo. 4 . fo. 77 .

${ }^{50}$ Mogilev governor to minister of internal affairs, letter of 12 June 1862, ibid., 
IRGS ${ }^{51}$ and was supported by the Minister of Education Aleksandr Golovnin, ${ }^{52}$ who intimated to the tsar about such an expedition in his report of 8 September 1862 . The latter both approved the idea and prescribed to earmark 10,000 roubles for the organization of the expedition, which was to take place the following year, in $1863 .{ }^{53}$ The preparation of the expedition was entrusted to the IRGS. It set up a special commission which several times discussed the issue in the sittings of the departments of ethnography and statistics in 1862-1863. In 1862 one of the leaders of the Ukrainophile movement Nikolai Kostomarov seems to have participated in the preparation of the plan of the expedition. The management of the expedition, divided into three sections, was committed to people whose political loyalty could not raise any doubts. Research into ethnography was led by the prominent Slavophile Aleksandr Gilferding, into religions by Mikhail Koialovich, professor of the St Petersburg Orthodox Spiritual Academy, and the economic situation was investigated by Artur Bushen's group which also comprised three statistics specialists. ${ }^{54}$ It seems that Piotr Shchebalskii, ${ }^{55}$ whom the local authorities intended to enlist in the publication of a magazine for the people, ${ }^{56}$ was also to join the expedition. The expedition had to gather statistics in three groups of gubernias, in the Belorussian (Vitebsk, Mogilev and Minsk), Lithuanian (Vilna, Kovno and Grodno) and Ukrainian (Kiev, Volyn and Podole) gubernias. ${ }^{57}$

${ }^{51}$ P. P. Semenov, Istoriia poluvekovoi deiatel'nosti Imperatorskago Russkago Geograficheskago obshchestva, 1845-1895, p. 1 (St Petersburg, 1896), p. 375.

${ }^{52}$ Incidentally, Golovnin was an initiator of literary ethnography, see C. B. Clay, 'Russian Ethnographers in the Service of Empire, 1856-1862', Slavic Review, 54 (1995) p. 48.

${ }^{53}$ Minister of education to vice-president of the IRGS Fedor Litke, letter of 8 Sept. 1862, Archive of the Geographical Society, St Petersburg (henceforth AGS), f. 1-1862, op. 1, d. 26, fo. 1; Trudy etnografichesko-statisticheskoi ekspeditsii v Zapadno-Russkii krai snariazhennoi Imperatorskim Russkim Geograficheskim obshchestvom. Iugo-Zapadnyi otdel. Materialy i izsledovaniia sobrannyia P. P. Chubinskim, vol. 1, no. 1 (St Petersburg, 1872), p. iii.

${ }^{54}$ IRGS to the minister of internal affairs, letter of 30 Nov. 1862; IRGS to A. G. Troinitskii, letter of 7 Dec. 1862, RGIA, f. 1290, op. 1, d. 337, ff. 4, 5.

${ }^{55}$ Shchebalskii to M. Katkov, copy of a letter of 14 Jan. (s. a., possibly 1863), Russian State Library, Moscow, Manuscript Division, f. 120, karton 22, f. 189.

${ }^{56}$ Z. Medišauskienè, 'Carinès valdžios sumanymas leisti liaudžiai skirtą žurnalą rusų ir žemaičių kalbomis XIX a. 7-ajame dešimtmetyje’, Atgimimo istorijos studijos, vol. 4: Liaudis virsta tauta (Vilnius, 1993), pp. 449-478.

57 Zhurnal zasedaniia Soveta Imperatorskago Russkago Geograficheskago obshchestva 23 oktiabria 1862 goda, Zapiski Imperatorskago Russkago Geograficheskago obshchestva (henceforth Zapiski), book 1, 1863, p. 26. 
The political aims of the expedition became evident in the debates of the IRGS. One of the experts explicitly linked the work of the expedition with nationality politics: the expedition had to establish which ethnic group (plemia) predominated in a particular territory and to determine the national composition of the gentry and officialdom. Operating with such data, the government could (1) refute erroneous fabrications by westerners about Poland; (2) protect each ethnic group and faith from the domination of the other; (3) having determined the prevalent ethnic group (narodnost') introduce its language as a medium of tuition; and (4) ensure that the ratio between believers, priests and places of worship in various faith groups would be equal. ${ }^{58}$ At the session of the IRGS the commission presented its own considerations maintaining that the collected data would 'indicate the circumstances obstructing the moral and economic well-being of the plemia, numerically prevailing (Belorussians, Lithuanians and Little Russians), and in the end would facilitate the government to find ways of improving that situation' ${ }^{59}$

Although the political implication of the expedition was evident, the preconceived bias in selected the sources was somehow absent. Gilferding, Koialovich and, to some extent, Bushen had to tour the Western province (they even prepared preliminary routes) and to survey the population. The IRGS was to collect the statistical information firstly in the major centres. ${ }^{60}$ The Statistics Department of the IRGS emphasized that the most important and demanding task was to check up the local sources, since no expedition was able to re-count the population of $11,000,000 .{ }^{61}$ Meanwhile, Bushen, who was also responsible for the collection of statistical data, presented an even more ambitious plan. Accordingly, the members of the expedition had to use available sources (the materials of the Central Statistics Committee, of the statistics committees of the gubernias, those presented by the non-Orthodox clergymen, etc.); these materials had to be verified by visiting all the districts. Thus, even data collected by the non-Orthodox were considered acceptable on condition that

${ }^{58}$ A draft outline for the expedition by an unknown author, AGS, f. 1-1862, op. 1, d. 26, ff. 29-30.

59 Zhurnal zasedaniia Soveta Imperatorskago Russkago Geograficheskago obshchestva, 23 Oct. 1862, Zapiski, book 1, 1863, p. 27.

${ }^{60}$ Ibid.

${ }^{61}$ Zhurnal otdeleniia Statistiki Imperatorskago Russkago Geograficheskago obshchestva, 10 Nov. 1862, Zapiski, book 1, 1863, p. 55. 
they were assessed critically. The census-takers had to check the available data on the basis of their own observation and to collate it with the information supplied by clergymen and landowners (regardless of their religious affiliation), and by local authorities, in particular by district starostas and vybornye. ${ }^{62}$

Though the commission of the expedition, set up by the IRGS, indicated in the fieldwork programme that ethnic differences (plemennye razlichiia) 'manifest themselves in the language, character and customs',63 it could seem strange that in the expedition ethnographic and statistical data had to be collected separately. Thus, Gilferding was not sure whether 'the people, which we call Belorussians, consists of one plemia or of several them' ${ }^{64}$ Taking into consideration a still fluid conception of nationality in the contemporary public and official discourses it could happen that one and the same expedition could be guided by different criteria.

The incipient 'rebellion' made the expedition delay the organization and departure at the beginning of February. ${ }^{65}$ However, the need for the statistical data remained, and the minister of education, Golovnin, proposed to re-issue Šafarik's ethnographic map of the Slavs, ${ }^{66}$ supplemented by new data. ${ }^{67}$ The Department of Ethnography supported this idea. According to the commission, the most complicated problem was not the mapping of the area inhabited by the Slavs beyond the boundaries of the Russian Empire or the territories in which the Great Russians predominated, but the lands inhabited collectively by the Ukrainians, Belorussians, Lithuanians and Poles, i.e. the drawing of an ethnographic map of the Northwest Province. The worst of it was the mistrust of ethnographic statistics

${ }^{62}$ Bushen, Plan deistvii statisticheskogo Otdela ekspeditsii v zapadnye gubernii, AGS, f. 1-1862, op. 1, d. 26, ff. 77-78.

${ }^{63}$ Zhurnal zasedaniia Soveta Imperatorskago Russkago Geograficheskago obshchestva 23 oktiabria 1862 goda, Zapiski, book 1, 1863, p. 26.

${ }^{64}$ The fieldwork programme of ethnographic research, prepared by A. Gilferding, AGS, f. 1-1862, op. 1, d. 26, fo. 66.

${ }^{65}$ Minister of internal affairs to minister of education, a copy of a secret letter of 2 Febr. 1863, RGIA, f. 1290, op. 1, d. 337, ff. 10-11, 12.

66 Šafarik was very often quoted by Russian ethnographers and nationality statistics experts: cf. Kepen, 'Novya svedeniia', p. 113; Materialy ... Grodnenskaia gubernia, p. 622; Materialy ... Vilenskaia gubernia, p. 291 and elsewhere.

${ }^{67}$ Zhurnal zasedaniia Soveta Imperatorskago Russkago Geograficheskago obshchestva 13 marta 1863 goda, Zapiski, book 1, 1863, p. 170; Semenov, Istoriia, p. 379. 
supplied by parishes, which often indicated Slavic tribes that had become extinct long ago. The best criterion was considered 'the spoken language of the people'; therefore speech specimens had to be attached to the data presented by a priest or 'local observer'. The commission considered that such results could be obtained if the census-takers were given detailed instructions. Golovnin supported the ideas of the commission, nevertheless he considered that the time was not yet ripe for such a collection of ethnographic material, and this undertaking was postponed. ${ }^{68}$

At the Start of 'the Rebellion' The so-called January Uprising, which began in 1863, was an additional stimulus to surveying the national composition of the country. The press often reported concern about the ethnic composition of the Northwest Province, about which the public allegedly knew less than they did about the savage tribes of Africa. ${ }^{69}$

In the course of 'the rebellion', when the endeavours of the IRGS did not succeed, the Ministry of Internal Affairs decided to gather information through its own institutions. The use of the subsequently collected data shows that in addition to the aforementioned general anti-Polish tendencies and the need to better understand the polyethnic variety of the Empire in the context of the reforms, there were some more reasons linked with internal relationships in the political elite (that will be discussed later). The Central Statistics Committee actually was interested only in the data relating to the social elite, i.e. the faith and nationality (narodnost') of the gentry and townspeople, while information on the peasantry, though desirable, was less necessary. ${ }^{70}$ As the data had to be presented in a month's time and be collected in secret, the governors (to be more precise, their authorized local statistics committees) were charged with no easy task.

The central authorities needed the data urgently, and Troinitskii proposed a rather original counting technique: to deduct either the number of the non-Russians (Poles, Lithuanians, Germans, etc.) or the number of the non-Orthodox (Catholics, Lutherans, Jews, etc.) from the total number of the inhabitants and to treat the rest as 'Russians or people of Orthodox origin'. ${ }^{71}$ However, the Vilna

${ }^{68}$ Semenov, Istoriia, pp. 379-382.

69 'Ocherki Belorusskago Poles'ia', Vestnik Zapadnoi Rossii. Istorikoliteraturnyi zhurnal, god v, 1867, book viii, part iv, p. 107.

${ }^{70}$ Vice-minister Troinitskii to the eight governors of the Northwest Province, letter of 8 Oct. 1863 , RGIA, f. 1290 , op. 2 , d. 6 , fo. 1.

${ }^{71}$ Ibid. 
Statistics Committee, at least, preferred a different method of gathering information. Kirkor, who was entrusted with this task, made use of data already collected. Besides, the material was verified by consulting clergy of various faiths as well.

The information presented did not always reveal what kind of the criteria had been used. Thus, at the request of the statistics committee the Evangelical Lutheran pastor of Vilnius wrote: 'With the exception of an insignificant number of Jews, who have converted to Evangelical Lutheran Christianity, to my knowledge, all other parishioners of the Lutheran Church are of German origin'. ${ }^{72}$ After having received data from nine Western gubernias, the Central Statistics Committee had to state that 'some see the main differences in language, others in religion, still others in historical origins'. ${ }^{73}$ Nevertheless, the gathering of these statistical data revealed one tendency: the authorities defined the nationality of the lower social stratum (peasantry) and that of the social elite (mainly, the gentry) differently. The Vilna Statistics Committee (and Kirkor) indicated language as a marker in the ethnic differentiation of the peasants, ${ }^{74}$ while the Central Statistics Committee additionally noted that 'the plemia origin ... in the lowest estates was obscured by religious differences'. ${ }^{75}$ In respect to the gentry, both Kirkor and the officials of the Central Statistics Committee acknowledged that ethnicity, though it could be determined (e.g. judging by surnames), was not central for the ascertaining of nationality. Those members of the gentry who professed Catholicism, spoke Polish and observed Polish customs had to be considered Poles despite their Lithuanian or Belorussian origin. ${ }^{76}$

Still during 'the rebellion' two ethnographic atlases were prepared and published; together with the materials collected by the Central Statistics Committee they invigorated discussions on the national composition of the Northwest Province in the Russian press.

72 Vilnius Evangelical Lutherans to the Statistics Committee of Vilna Gubernia, letter of 23 Oct. 1863, LVIA, f. 388, ap. 1, b. 334, fo. 9.

${ }^{73}$ Commentaries to the statistics tables, Iz del Zapadnogo kommiteta, Russian National Library, St Petersburg, Russkii fond, 18.241.8/1-29 (unnumbered pages).

${ }^{74}$ [Kirkor], On the population numbers according to nationalities (narodnost ), LVIA, f. 388, ap. 1, b. 334, ff. 15-16; Vilna Statistics Committee to Prelate Bobnevičius of the Vilnius Catholic Diocese, undated, ibid., fo. 24.

${ }^{75}$ Commentaries to the statistics tables, Iz del Zapadnogo kommiteta, Russian National Library, St Petersburg, Russkii fond, 18.241.8/1-29 (unnumbered pages).

${ }^{76}$ [Kirkor], On the population numbers according to nationalities (narodnost ${ }^{\text {) }}$, LVIA, f. 388, ap. 1, b. 334, ff. 15-16. 
R. Erkert drew on the official data, however his work most probably was not 'officially commissioned and was done on his own initiative'. ${ }^{77}$ Although Erkert's atlas argued that this region was Russian rather than Polish ${ }^{78}$ it was criticized by many authors. The point was that he treated religion as a criterion of nationality (natsional'nost'):

In the gubernias, where the Poles are mixed with the Russians, nothing reveals the boundary between the two nationalities so assuredly and persuasively as the difference between their faiths; thus, almost without any exception, the entire Slavic population in the above indicated regions, professing the Roman Catholic religion, must be considered Polish, and the whole Slavic population professing the Graeco-Russian faith the Russian population. ${ }^{79}$

It is to be noted that even those who criticized this kind of interpretation of nationality, as e.g. Koialovich, did not disclaim the importance of religion for national identity, ${ }^{80}$ however, they drew attention to the specifics of the Western region:

With regard to common people, which must be the main subject of ethnography, the Roman religion alone cannot serve as the main criterion of nationality in their life. Their relationship to the faith is too immediate and too detached from the Polish gentry for the Roman religion to have the same national attraction as for the Polish gentry. ${ }^{81}$

In this case not only the numbers indicating the ratio between the Poles and the Russians but also the motives related to ethno-politics were important. The proposal not to confine oneself solely to religion was primarily associated with the treatment of Belorussian Catholics. Despite the Catholicism professed by some Belorussians, Koialovich tended to consider them 'potential Russians'. The hope that they could soon become Orthodox was even not kept secret.

77 A. N. Pypin, Istoriia russkoi etnografii, vol. iv: Belorussiia i Sibir' (St Petersburg, 1892), p. 102.

${ }^{78}$ M. Koialovich, O rasselenii plemen Zapadnago kraia Rossii (Moscow, 1863), p. 7.

79 R. F. Erkert, Etnograficheskii atlas Zapadno Russkikh gubernii $i$ sosednikh oblastei (St Petersburg, 1863), pages unnumbered.

${ }^{80}$ It can be added that some time later Koialovich became a most outspoken opponent of the introduction of the Russian language into Catholic services outside the Mass. The opponents of this project argued that in such a way the boundary between the Russians and the Poles would be eliminated.

${ }^{81}$ Koialovich, 'Vzgliad g. Erkerta na Zapadnuiu Rossiiu', Vilenskii vestnik, 1864, Nr. 97. 
'You ought to see how often Western Russian peasants of Latin faith apply to Orthodox priests for certain sacramental rites in the belief of finding in them greater strength than in the Latin ceremonies' 82

The criticism of Erkert's atlas enables one to understand why the other atlas, compiled by Aleksandr Rittikh was received more favourably by the Russian press. ${ }^{83}$ Rittikh did not explain in greater detail how nationality was defined. However, the copious sources on which he drew and the fact that he separated the Žemaitians from the Lithuanians shows that language was a major criterion. ${ }^{84}$ In this case the atlas was prepared 'on the basis of the most accurate and indubitable data rather than on fortune-telling and naked assertions', 85 and, no doubt, the data obtained showed the number of the Poles in the Western region smaller by several hundred thousand in comparison to Erkert's count.

The statistical material, compiled during the uprising had a certain practical purpose. Thus, Rittikh's atlas had to contribute to the rational allocation of the churches, and its propaganda function was important, too. ${ }^{86}$ The endeavour to show smaller numbers of the Poles was necessary in the propaganda war which the Empire waged abroad. Therefore it is small wonder that Erkert's atlas was issued in French, too. ${ }^{87}$ No less significant were the chances of using

${ }^{82}$ Ibid.

83 'Zametka po povodu izdaniia Atlasa narodonaseleniia zapadno-Russkago kraia po veroispovedaniiam', Vestnik Iugo-zapadnoi i zapadnoi Rossii. Istorikoliteraturnyi zhurnal, dekabr', god ii, vol. ii (Kiev, 1864) otg. IV, pp. 287-301; 'Atlas Rittikha (Bibliograficheskaia zametka)', ibid., mart, god ii, vol. iii, otg. IV, pp. 314 317; 'Eshche bibliograficheskaia zametka ob atlase zapadnoi Rossii po veroispovedaniiam”, ibid., mai, god ii, vol. iv, otg. IV, pp. 272-276, ff.

${ }^{84}$ The preparation of the atlas was begun by Batiushkov in 1859. Attention was first paid to the state of the Orthodox churches on the estates. The sources of the dioceses, the Department of Foreign Confessions, the Central Statistics Committee, the Imperial Academy of Sciences, the works of Bobrovskii, Afanas'ev, Lebedkin, a. o. were used.

${ }^{85}$ Atlas narodonaseleniia Zapadno-Russkago kraia po veroispovedaniiam sostavlen pri Ministerstve vnutrennikh del v kantseliarii zaveduiushchego ustroistvom pravoslavnykh tserkvei $v$ Zapadnykh guberniiakh, 2nd revised ed. (St Petersburg, 1864), unnumbered pages.

86 R... (?), 'Atlas narodonaseleniia Zapadno-Russkago kraia po veroispovedaniiam', Zapiski Imperatorskago Russkago Geograficheskago obshchestva, book 1, 1864, p. 7.

${ }^{87}$ R. Erkert, Atlas Ethnographique des provinces habitées en totalité ou en partie par des polonais (St Petersbøurg, 1863). Unfortunately, we failed to reveal the circumstances of the publication of this atlas. 
the collected nationality statistics at home. It is noteworthy that in this case the ratios rather than exact figures were important. Following the uprising a particular discriminatory political action was often based on nationality statistics in the official documents. Thus, the ban for 'persons of Polish origin' to acquire land was based on the statement that 'in the nine western gubernias the population of Polish origin is relatively exceedingly small in the total population of ten million, mostly Little Russian, Belorussian and partly LithuanoŽemaitian' and that the Poles would 'be an obstacle for the rest of the population, not at all Polish, to develop naturally and to enjoy the reforms, envisaged by His Majesty, on an equal footing with all other subjects' ${ }^{88}$ Here it is worth recalling that the purpose of the ethnographic expedition in the Western region was to find out what factors obstructed the development of these ethnic groups.

Nationality statistics were also of interest to the imperial elite in its internal struggle. The Russian character of this region was frequently accentuated by the governor general of Vilnius Mikhail Murav'ev, a proponent of a strict anti-Polish policy. Sometimes he even submitted figures which were at variance with the then well known data. Proposing a plan for nationality policy measures in the Northwest Province, he wrote that five sixths of the population in the region were Russians of the Orthodox faith. ${ }^{89}$ Mikhail Dolbilov was probably right supposing that in this case the Vilna governor general could say so since of the six gubernias under his control the Catholics 'absolutely' predominated only in one - the Kovno Gubernia. ${ }^{90}$ In this case Murav'ev did not disagree with the conception fostered by the contemporary Russian ethnographers that the

${ }^{88}$ December 10, Imperial Decree released for the Senate by the Minister of Justice December 22. - O vospreshchenii litsam Pol'skogo proiskhozhdeniia vnov' priobretat' pomeshchich'i imeniia $\mathrm{v}$ deviati zapadnykh guberniiakh, o predostavlenii vyslannym iz Zapadnogo kraia vladel'tsam sekvestrirovannykh imenii prava prodat' ili promeniat', v dvukhgodichnyi srok, svoi imeniia v etom krae litsam Russkogo proiskhozhdeniia, i voobshche o poriadke soversheniia aktov na perekhod imenii v Zapadnom krae k russkim vladel'tsam, Polnoe sobranie zakonov Rossiiskoi imperii, collection 2, vol. xi, division 2, 1865 (St Petersburg, 1867), pp. 326-327.

${ }^{89}$ [Murav'ev], 'Zapiska o nekotorykh voprosakh po ustroistvu SeveroZapadnogo kraia, podana 14-go maia 1864', Sbornik statei, raz'iasniaiushchikh pol'skoe delo po otnosheniiu $k$ Zapadnoi Rossii, ed. S. Sholkovich (Vilnius, 1885), p. 308.

${ }^{90}$ M. Dolbilov, 'Kul'turnaia idioma vozrozhdeniia Rossii kak faktor imperskoi politiki v Severo-Zapadnom krae v 1863-1865 gg.', Ab Imperio, 1-2/2001, p. 232. 
region's ethnic character was defined by the numerically predominating ethnic group. The minister of internal affairs Piotr Valuev, an opponent of Murav'ev's policy, tended to rely on more accurate statistics, which showed that the Russians were not at all a totally dominant group in this country. ${ }^{91}$ Later Valuev also used the materials, collected by the Central Statistics Committee, trying to prevent, in his opinion, excessive measures aimed at replacing civil servants of 'Polish origin' with Russians, since 'you must not expel 850,000 Poles from Russia and you must not make all the natives of the Western region serve, say, in the Volga region, and those of the Volga region in the Western region' ${ }^{92}$

After the Uprising of 1863-1864 Although in the years of the Uprising a number of works were published on nationality statistics from this region, subsequently attention to this issue did not subside, either. More books were published, sometimes drawing on earlier collected data. ${ }^{93}$ New material had to be provided by research into settlements conducted by the Central Statistics Committee, by a renewed expedition to the Western region and by the Northwest Department of the IRGS. Both the organization of the expedition and the establishment of the new department were fraught with certain difficulties due to the minister's resistance. True, Valuev's

${ }^{91}$ Ibid., pp. 231-232.

92 The account of the minister of internal affairs of 7 Aug. 1863 about the Western and Baltic gubernias (bearing the tsar's comments), GARF, f. 678, op. 1, d. 1133, ff. 2-3; Dnevnik P. A. Valueva, ministra vnutrennikh del, v dvukh tomakh, vol. 1, 1861-1864, (Moscow, 1961), pp. 294, 417. This data was used by the minister in his debate with an influential publicist, Mikhail Katkov: 'Pis'ma M. N. Katkova k P. A. Valuevu', Russkaia starina, June, 1916, pp. 355-356.

${ }^{93}$ N. Stolpianskii, Deviat' gubernii Zapadno-Russkago kraia v topograficheskom, geognosticheskom, statisticheskom, etnograficheskom i istoricheskom otnosheniiakh (St Petersburg, 1866).

${ }^{94}$ In 1865 the minister considered that it was too early to send an expedition to this region. In 1866 he at first refused permission to set up a Northwest Department of the IRGS, since 'the Northwest guberniias in terms of administration and situation did not exhibit any particular differences compared with some other Russian gubernias'. Such arguments disagreed with the strategy which the minister then advocated countering the attempts of the radicals seeking to treat both the Russian and the Northwestern gubernias equally and he constantly emphasized that their ethno-social and ethno-cultural specifics had to be taken into account. Nevertheless, the overseer of the Vilna Educational Region Ivan Kornilov and his like-minded fellows gained their aims, and on 26 Feb. 1867 Alexander II granted a permit to establish that department. Cf. minister of internal affairs to Litke, letter of 27 March 1865, RGIA, f. 1290, op. 1, d. 337, fo. 16; file 'Ob uchrezhdenii v Severo-zapadnom 
motives were rather formal. ${ }^{94}$ Therefore it is seems likely that he feared that gathering new data could be associated with the aspirations for a more radical assimilatory policy which he did not support.

After the suppression of the Uprising, the ideological motives, i.e. the endeavour to refute Polish 'inventions', and to prove the Russianness of the region was one of the main reasons in recording nationality statistics or describing ethnography. In one of the joint sessions of the IRGS Departments of Ethnography and Statistics A. V. Rachinskii discoursed on the priorities of a Slavophile programme:

Preserving the historical knowledge (which is not to be separated in the direct research of the subject) between people's sympathies and antipathies, we determine the correct attitudes towards White-, Little-, Black-, Red- and Great-Russians as Russians by determining their differences with the only aim in view to ascertain the similarities and identities; the same common Slavic similarities should be sought after in the Poles, carefully and lovingly cleaning the large body of the Slavic Pole of Latin age-old incrustations. ${ }^{95}$

One of the principal tasks of this activity was to define the boundaries separating various ethnic groups of the Western Region and to describe their economic activity, customs, etc. The establishment of national areas, naturally was supposed to contribute to the formation of nationality policy, and changes made in them were to support or reject a particular course. Such assessment of the contemporary situation was confirmed by the ethno-political programmes of certain figures (such as Koialovich and Gilferding, among others) actively participating in this field of activity. The Russian press sometimes contained hints about the necessity of taking interest, for example, in Lithuanians, as that would draw them away from the Poles and make them Russian allies. ${ }^{96}$ The connection between

kraie otdela Imperatorskago Russkago Geograficheskago obshchestva', LVIA, f. 378, BS, 1866, b. 1544; Vilnius governor general to the overseer of the Vilna Educational Region, letter of 30 Sept. 1866, VUB RS, f. 34, b. 666, fo. 7; Semenov, Istoriia, p. 382; V. I. Dovgialo, 'K istorii Severo-Zapadnogo Otdela (Materialy i zametki)', Zapiski Severo-Zapadnago otdela Imperatorskago Russkago Geograficheskago obshchestva, book 1 (Vilnius, 1910), pp. 11-20.

${ }^{95}$ AGS, f. 1-1867, op. 1, d. 26, ff. 143-144.

${ }^{96}$ Koialovich, O rasselenii plemen Zapadnago kraia Rossii (Moscow, 1863), p. 22; Gilferding, 'Neskol'ko zamechanii o litovskom i zhmudskom plemeni', Sbornik statei, ed. Sholkovich, pp. 106-127. At first this article was published by Gilferding in the newspaper Den' (no. 8, 1864), and afterwards in the supplement to another periodical Russkii invalid (no. 5, 1864). 
ethnographic descriptions national stylistics and nationality policy was revealed possibly most clearly in preparations for the IRGS expedition. Among its aims it envisaged the determination of the effect of the contemporary reforms on the ethno-cultural situation: 'the researcher should pay attention to the extent to which events of recent years contributed to the strengthening of the Great-Russian element in the commerce and industry of Western Russia'. ${ }^{97}$ Meanwhile, Iulii Kuznecov had to determine the attitudes of Lithuanians and Latvians towards the ongoing reforms. ${ }^{98}$

In addition to the subject of the traditional concentration of ethnographic attention - the peasantry - in the 1860s there appeared a new element, namely the Jews ${ }^{99}$, and that was also associated with the development of the nationality policy. At the time of the 'rebellion' and several years after it no wider significance was attached to the Jews in the nationality policy in the Western region. Since the middle of the 1860s this ethno-confessional group had been attracting increasing attention. It is credible that after the suppression of the Uprising and after the introduction of many discriminatory measures directed against the Poles the authorities decided that, on the one hand, the anti-governmental activity was curbed, at least for the time being, and on the other, the imperial elite perceived that the Poles would nevertheless remain the enemies of the state's integral unity. These two circumstances could encourage the authorities to pay greater attention to a rather numerous Jewish community in the Northwest Province.

While collecting ethnographic material emphasis was placed not so much on published data as on the observations of the censustakers. ${ }^{100}$ Besides, they had to meet new requirements. The organization of the IRGS expedition and the establishment of its Vilnius

${ }^{97}$ Semenov, Istoriia, p. 384.

${ }^{98}$ The programme, drawn by L. Maikov and revised by Semenov for Kuznecov's work (comprising Gilferding's remarks), AGS, f. 1-1862, op. 1, d. 26, f. 286.

${ }^{99}$ Koialovich's report 'On the expedition to Western Russia', delivered at the joint session of the IRGS Committees of Statistics and Ethnography, ibid., ff. 133140; the session of the Department of Statistics of the Northwest Division of the IRGS, 20 Oct. 1867, VUB RS, f. 34, b. 671, ff. 2-3; 'Uchennaia ekspeditsiia v Zapadnyi krai', Vilenskii vestnik, no. 21, ff.

100 The programme, drawn by Maikov and revised by Semenov for Kuznecov's work (comprising Gilferding's remarks), AGS, f. 1-1862, op. 1, d. 26, ff. 285-287; A. Sementovskii, Etnograficheskii obzor Vitebskoi gubernii, (St Petersburg, 1872), p. 3. 
department are evidence of mistrust in the former techniques of data collection. Following the suppression of the Uprising reliance on data gathered by the clergy, in particular by Catholics, declined. ${ }^{101}$ There was a presumption that they consciously indicated smaller numbers of 'Russians'. ${ }^{102}$ In some cases the exaggeration of the numbers of Lithuanians seems to have been simply due to ignorance, i.e. the uncertainty to what ethnic category those speaking 'the peasant dialect' (po khlopski) ${ }^{103}$ should be attributed. Therefore it is no wonder that the first draft of the IRGS Northwest Province's statutes contained a provision that only Russians could be its members. ${ }^{104}$

Such an attitude to the selection of fieldworkers could be effective in ideological terms, but there were always problems primarily related to competence and the perception of nationality. Thus, in 1866 and 1867 compiling a list of settlements in the Northwest region, the data on the faith and 'origin or nationality' (narodnost') of the population had to be recorded as well. The information presented by local police officials was far from satisfactory: sometimes faith or nationality were not indicated at all, origin was indicated in the confession column and vice versa; nationality was at times defined as 'indigenous' (tuzemets); people of Jewish origin were referred to as 'Lithuanian-Russian' or 'Lithuanian', etc. ${ }^{105}$ The press also criticized reference to long-extinct tribes, such as Yatvingians or Krivichi. 106

In discussions of nationality criteria, reference was still sometimes made to religion as the most significant feature distinguishing Russians from Poles. Nevertheless, ethno-linguistic views already pre-

${ }^{101}$ On the other hand, cf. a programme of the geographical and ethnographic data gathering, compiled by V. Gomolitskii at the Northwest Department of the IRGS, which seems to have been circulated to the clergy of all faiths; see the protocol, dated 25 Nov. 1869, of the organizing committee of the Northwest Department of the IRGS, VUB RS, f. 34, b. 674, ff. 9-10.

102 R... (?), 'Atlas narodonaseleniia Zapadno-Russkago kraia, po veroispovedaniiam', Zapiski, book 1, 1864, p. 17.

${ }^{103}$ Bobrovskii, 'Deviat' gubernii Zapadno-Russkogo kraia', Vilenskii vestnik, 1866, no. 254.

${ }^{104}$ A copy of the project of the statute of the Northwest Province of the IRGS, VUB RS, f. 34, b. 666, ff. 2-3; Eglè Tamulevičienè, 'Rusu geografų draugijos Šiaurès vakaru krašto skyrius (1867-1915)', Mokslo draugijos Lietuvoje (Vilnius, 1979), p. 34. This stipulation was eliminated at the insistence of the leadership of the IRGS.

${ }^{105}$ File 'Po otnosheniiu Tsentral'nago Statisticheskago Komiteta o sostavlenii spiskov naselennykh mest Vilenskoi gubernii', LVIA, f. 388, ap. 1, b. 387.

${ }^{106}$ Bobrovskii, 'Deviat' gubernii'. 
dominated. The endeavour to prove that not all Catholics were Polish ${ }^{107}$ was associated with the desire not to lose 'potential Russians' Belorussian Catholics. Therefore language was recognized as the principal trait of nationality (narodonost') in ethnographic descriptions, articles and in the preparation of expeditions to the Western region. ${ }^{108}$ It is worth noting that Russian ethnographers emphasized that it was the native tongue that was meant in this context, i.e. 'the language spoken since childhood, permanently used in the family every day and passed on, so to say, from father to son'. ${ }^{109}$ It was quite credible that in the absence of such a specification the language, prevalent in the social communication, could be recognized officially; and such a language in some Belorussian areas was Polish, as it was used in the Catholic Church. True, the role of language was not made unconditional. Account had also to be taken of 'how the inhabitants identified themselves, their past, way of life, character, their likings and political beliefs'. ${ }^{110}$

$* * *$

The increase in nationality statistics and ethnographic descriptions in the Russian Empire in the mid-nineteenth century could be linked to the modernization of the state. The implementation of many reforms was impossible without statistical information and knowledge about the national composition of the population. For example, the reform of primary education on the fringes of the Empire could be carried out only by taking into account the local inhabitants' native tongue.

In the Northwest Province (and that held good for the entire Western region) there were extra motives for the authorities to be interested in ethnographic descriptions and nationality statistics. These data were also necessary in conducting a propaganda war against the Poles (to prove that the region was Russian rather than Polish) and in planning various nationality policy campaigns, e.g. establishing new administrative boundaries for the gubernias.

${ }^{107}$ File 'O sobiranii ststisticheskikh svedenii o kolichestve poliakov i lits drugikh national'nostei Zapadnogo kraia, prinadlezhashchikh k katolicheskomu ispovedaniiu', RGIA, f. 821, op. 150, d. 99.

${ }^{108}$ Sementovskii, Etnograficheskii obzor, pp. 2-3; the programme, drawn by Maikov and revised by Semenov for Kuznecov's work (comprising Gilferding's remarks), AGS, f. 1-1862, op. 1, d. 26, ff. 285-287.

${ }^{109}$ Sementovskii, Etnograficheskii obzor, pp. 2-3.

${ }^{110}$ Ibid. 
The politicization of this sphere was attested by the growing mistrust in the statistical material, collected by 'the Poles' (mainly by the Catholic clergy).

Although Russian ethnographers did attach particular significance to language as a criterion, handy for the imperial authorities in determining nationality, even in the mid-nineteenth century there were frequent cases when priority was given to faith rather than language. That showed how deeply ingrained the association between confession and nationality was in Russian public discourse at that time. Meanwhile when referring to the social elite (primarily the gentry) observers laid stress on faith, culture, political aspirations and language too. Although in ideological terms it was convenient to place emphasis on the Russian or Lithuanian origin of the majority of the gentry, ethno-political reality (Catholicism, professed by the gentry, the use of the Polish language, political aspirations, in other words, self-identification) already prevented such an emphasis from being made.

Translation: Alfonsas Laučka

\section{Author Details}

Dr Darius Staliūnas specializes in Russian nationality policy in the Nortwest Province (in what is now Lithuania and Belarus).

Address: Department of the 19th-Century History, Lithuanian Institute of History, Kražiu 5, 01108 Vilnius, Lithuania

Email: staliunas@istorija.lt 
TAUTINÉ STATISTIKA IR RUSIJOS POLITIKA (XIX A. 6-7 DEŠ.)

\section{Santrauka}

\section{DARIUS STALIŪNAS}

XIX a. I pusėje Rusijos imperijos multietniškumas nebuvo labai rimta politinė problema valdančiajam elitui, tačiau modernizacijos procesas bei tautinès problemos priverte Rusijos valdžią atkreipti dèmesị i etninę valstybės įvairovę. Siekimas efektyviau valdyti didelę imperiją ir politinès priežastys skatino tautinius surašymus. Šiame straipsnyje daugiausia dèmesio skiriama klausimui, kokios priežastys paskatino tautinius surašymus Rusijos imperijos Šiaurès vakarų krašte (šiandieninëje Lietuvoje ir Baltarusijoje) XIX a. viduryje, kaip keitèsi statistikos rinkimo metodai ir kaip vèliau surinkta medžiaga buvo naudojama politiniams tikslams.

I tautinès statistikos rinkimą nereikètų žiūrèti tik kaip į ideologinį instrumentą. Valdžiai reikejjo kaip galima tikslesniu ,,pakraščių“ tautinès statistikos duomenų, kad galètų efektyviau valdyti bei fiksuoti tautinès politikos rezultatus.

Vis dèlto tautiniai surašymai naudoti ir politiniams tikslams, tai rodė vis didejjantis valdžios nepasitikèjimas „lenkų“ (pirmiausia katalikų dvasininkijos) surinkta statistine medžiaga. Nors Rusijos etnografai buvo sureikšminę imperijos valdžiai paranku kalbos kriterijų apibrěžiant liaudies tautiškumą, tačiau net ir XIX a. viduryje sutinkame ne vieną tautinès statistikos atveji, kaip prioritetas teiktas ne kalbai, bet konfesijai. Tai rodo, kaip stipriai to meto viešajame rusiškame diskurse buvo įsišaknijęs konfesijos ir tautiškumo tapatinimas. Tuo tarpu socialinio elito (pirmiausia bajorijos) tautine priklausomybę rodè konfesija, kultūra, politiniai siekiai, taip pat kalba. Nors ideologiškai kartais būdavo paranku akcentuoti daugumos bajorijos rusišką ar lietuvišką kilmę, tačiau etnopolitinè realybė (daugumos bajorijos išpažinta katalikybè, vartojama lenku kalba, politiniai siekiai (kitaip tariant, savimonè)) jau neleido to daryti.

Rusijos valdžia tautinę šio krašto statistiką naudojo tam, kad būtų ịodyta, esą šis kraštas yra ne lenkiškas, bet rusiškas. Kartu, žinoma, buvo naudojami ir kiti argumentai, pirmiausia - istoriniai. 